\title{
INVESTIGATION OF THE EMULSIFYING CAPACITY OF SNACK PASTE BASED ON FATLESS COTTAGE CHEESE
}

\author{
Petro Gurskyi \\ Department of equipment and engineering of processing and food production \\ Petro Vasylenko Kharkiv National Technical University of Agriculture \\ 44 Alchevskikh str., Kharkiv, Ukraine, 61002 \\ gurskyi_petro@ukr.net \\ Fedor Pertsevoy ${ }^{1}$ \\ kaf_th@meta.ua \\ Lidiia Kondrashyna ${ }^{1}$ \\ lidiya198331@gmail.com \\ ${ }^{1}$ Department of the nutrition technology \\ Sumy National Agrarian University \\ 160 G. Kondratieva str., Sumy, Ukraine, 40021
}

\begin{abstract}
Technological parameters of the process of refined deodorized sunflower oil emulsification in a protein base - fatless cottage cheese for making a snack paste are presented. The expedience of introducing a melting salt - sodium citrate as a main emulsifier and its concentration are substantiated.

It has been established, that with increasing a content of sodium citrate the emulsifying capacity of a protein base grows, and at its concentration $2.0 \%$, reaches the maximal value -50 vol un of oil. At a further increase of the sodium citrate concentration the emulsifying capacity decreases probably as a result of an abrupt $\mathrm{pH}$ growth.

It has been proved, that at adding dry skimmed milk in amount $4.0 \pm 0.5 \%$ as an additional emulsifier in the protein base of a snack paste at $40 \%$ of fatless cottage cheese in the recipe an increase of its emulsifying capacity by 6 vol un of oil, probably as a result of the growth of surface active substances, takes place.

The temperature influence on the viscosity of the snack paste protein base has been investigated and the rational concentration of refined deodorized sunflower oil has been determined as $25 \pm 2 \%$.

It has been established, that the temperature decrease from 50 to $30{ }^{\circ} \mathrm{C}$ and content increase of sunflower oil in the protein base from $25 \pm 2 \%$ to $30 \pm 2 \%$ result in the essential viscosity increase that may worsen emulsifying conditions.

It has been proved, that emulsion stability that is an important parameter for a snack paste of the emulsion type with a long storage term depends on content of main protein-containing components, sunflower oil and active acidity of the protein base.

The obtained results have a practical importance for determining the rational concentration of refined deodorized oil and sodium citrate that provides more necessary emulsifying capacity of the protein base and emulsion stability at storage in the technology of snack pastes, based on fatless cottage cheese.
\end{abstract}

Keywords: technology of emulsion products, emulsifying capacity, protein base, inversion point, aggregative and kinetic stability of emulsion.

\section{Introduction}

A segment of snack products, based on milk protein, relates to high-competitive ones at the products market by its demand among the population of Ukraine.

It is known, that the main fat component in snack products of the modern product market is milk fat, contained by hard cheeses - traditional protein base, and also as cream or cream butter. Milk fat gives snacks a creamy taste and consistence $[1,2]$.

But the essential decrease of milk production and its high cost in Ukraine created a deficit of milk fat, used in production of the essential spectrum of milk products [3]. At the same time new economic conditions of the market forced producers to search for less deficit and cheaper 
vegetable fat raw materials for its replacement with a synchronous increase of the biological and food value. It resulted in the wide use of different fats and their compositions for partial or complete replacement of milk fat. The key demand of replacing milk fat by vegetable oil is a food value increase and improvement of organoleptic parameters of milk products with a possible decrease of cholesterol content.

It is known, that milk fat contains little amounts of essential oils: linoleic acid is within $1.5 \ldots 4.4 \%$, linolenic $-0.2 \ldots 2.1 \%$, whereas the content on linoleic acid in sunflower oil reaches up to $60 \%[2,4]$.

Vegetable fats contain many vitally important essential polyunsaturated fatty acids and also vitamin E (tocopherol), playing an important role in the human organism [4]. Physical-chemical properties of milk fat and several vegetable oils [2, 4], according to the data of native scientists, are presented in Table 1.

A taste and smell of vegetable oil, used in the recipe of a snack paste as a fat component, must imitate the typical taste or be neutral and stable at storage of the ready product.

Table 1

Physical-chemical properties of milk fat and several vegetable oils

\begin{tabular}{ccccc}
\hline \multirow{2}{*}{ Name } & \multicolumn{2}{c}{${\text { Temperature },{ }^{\circ} \mathbf{C}}^{\text {congelation }}$} & $\begin{array}{c}\text { Saponification } \\
\text { number of }\end{array}$ & Iodine number \\
\cline { 2 - 4 } Melting & $28 \ldots 33$ & $18 \ldots 23$ & $220 \ldots 234$ & $28 \ldots 45$ \\
Silk fat & - & $-16 \ldots-19$ & $186 \ldots 194$ & $119 \ldots 145$ \\
Corn oil & - & $-10 \ldots-20$ & $187 \ldots 190$ & $111 \ldots 113$
\end{tabular}

The use of refined deodorized sunflower oil as a fat component allows not only to decrease costs and to raise productivity, but also gives a possibility to widen the assortment, allows to make products with a less cholesterol content or without it, to balance a content of saturated and polyunsaturated fatty acids.

The aim of the study is to substantiate a concentration of the main recipe components - fatless cottage cheese and refined deodorized sunflower oil in the technology of a snack paste of the emulsion type, using a melting salt as sodium citrate as a main emulsifier.

The series of tasks must be solved according to the set aim:

- to study the viscosity of the snack paste protein base;

- to study the dependence of the protein system viscosity on temperature;

- to study the emulsifying capacity of the protein base;

- to determine the emulsion aggregative and kinetic stability.

\section{Materials and Methods}

The research objects were fatless cottage cheese of cow milk by SSU 4554:2006, obtained by the method of acid-abomasum coagulation of protein, refined deodorized sunflower oil by SS 1129, melting salt - sodium citrate (E331i, 331iii), dry skimmed milk by SSU 4273:2003, made by spraying with the mass share of: moisture $5 \%$, fat $1.5 \%$, protein $32 \%$, lactose $50 \%$.

Conventional standard research methods were used. Emulsification was realized on a laboratory emulsifier. For this aim a sample of the snack paste protein base as fatless cottage cheese with volume $10 \mathrm{ml}$ was placed in a chemical glass with volume $100 \mathrm{ml}$, and added with refined deodorized sunflower oil with speed $78 \ldots 80$ drops/min up to the phase inversion moment [5-8].

\section{1. Determination of emulsion type}

The emulsion type was determined by the dilution method, which essence is that emulsions as "fat in water" keep stability at water dilution and become non-homogenous at adding fat, emulsions of the reverse type keep stability at adding fat, but become non-homogenous at adding water. 
A drop of the studied emulsion was put on an object-plate besides a water drop: drops mixture characterizes the emulsion "fat in water" $[5,6]$.

The volume of vegetable oil, poured from a funnel, corresponds to the phase inversion point value. The stability (constancy) of emulsions was determined, fixing phase volumes, separated after centrifuging with speed (33.3...35.0) $\mathrm{s}^{-1}$ during $(10 \ldots 11) \times 60 \mathrm{~s}$.

\section{2. Determination of emulsion viscosity}

The dynamic viscosity of the snack paste protein base as fatless cottage cheese with adding refined deodorized oil was studied in temperature diapason $30 \ldots 95^{\circ} \mathrm{C}$, heating and cooling samples with interval $5^{\circ} \mathrm{C}$ on Geppler rheo-viscosimeter [9], working by the principle of a displacing glass ball, falling in a liquid, produced by the plant FEB Karl Ceiss Yen with a tolerance for size and form distinctness less $0,001 \mathrm{~mm}$, which falling speed is a viscosity measure. The studies were conducted in two measuring cylinders by turns, one of which characterizes number 1 (normal liquid NF 1000), the other characterizes number 10 (normal liquid NF 10000). The shearing stress was measured by using special weights, included in the device set.

The dynamic viscosity was calculated by formula (1):

$$
\eta=P \cdot t \cdot K \cdot 30
$$

where $P$ - load, shearing stress, $\mathrm{g} / \mathrm{cm}^{2} ; t$ - research time, s; $K$ - measuring cylinder coefficient.

\section{3. Determination of emulsifying capacity}

The emulsifying capacity of the snack paste protein base was studied by determining the phase inversion point at emulsification, changing the concentration of one of main components of the protein base by the standard methodology at temperature $35 \ldots 40{ }^{\circ} \mathrm{C}$, moisture $77,6 \%$, with mixer frequency $25 \mathrm{~s}^{-1}$. The emulsifying capacity (\% of fat) was determined by the inversion point as a maximal amount of fat, emulsified in the studied solution to the inversion point $[5-8,10]$. The inversion point was determined by the abrupt decrease of voltage indications of the voltmeter, connected to the emulsification device.

\section{4. Determination of emulsion stability}

The total stability of model emulsions was determined by the method of constructing diagrams of emulsion stability that reflect the ratio of volumetric parts (\%) of the stable emulsion and phases, separated after centrifuging $[5,11,12]$. According to the data of obtained dependencies, there was estimated the effectiveness of the stabilized effect of the studied systems: the volumetric share of the fat phase was put on the x-axis, and volumetric shares of water and fat phases, separated in the centrifuging regime, were put on the y-axis from the left and right side, respectively. The lines, taken through experimental points, limit the area of separated phases and one of stable emulsion that may be a generalized measure of stability for the system "fat-water solution".

For studying the emulsion stability (constancy) of the emulsion before and after thermal processing, the diagrams were constructed by the standard method, that provides measuring of the volume of the fat and water phases, separated after centrifuging from the total volume as a result of emulsion destruction $[5,7,8]$.

\section{5. Statistical analysis}

The aggregative $(A s)$ and kinetic $(K s)$ stability were determined by formulas (2), (3) [5]:

$$
\begin{aligned}
& A s=100-\frac{H f}{H e} \times 100, \%, \\
& K s=100-\frac{H w}{H e} \times 100, \%,
\end{aligned}
$$


where $H f$ - height of the fat phase, separated after centrifuging, $\times 10^{-2} \mathrm{~m}$; He - height of the initial emulsion, $\times 10^{-2} \mathrm{~m} ; H w-$ Height of the water phase, separated after centrifuging, $\times 10^{-2} \mathrm{~m}$.

Each experiment was conducted with no less than 5 iterations. The regularities were reproduced in each equivalent experiment, and for the objective judgment about the reliability degree of the obtained data, the research results were mathematically processed, using the standard package Excel 2016.

\section{Results and discussion}

According to the data of authors [4], the viscosity difference of various deodorized refined oils is not essential and is in temperature diapason $90 \ldots 70{ }^{\circ} \mathrm{C}(1.2 \pm 0.2) \times 10^{3} \mathrm{~Pa} \cdot \mathrm{s}$, and in temperature diapason $50 \ldots 30^{\circ} \mathrm{C}-(2.5 \pm 0.1) \times 10^{3} \mathrm{~Pa} \cdot \mathrm{s}$.

For determining the rational concentration of sunflower oil at its emulsification in the protein base of snack pastes, the study of the dynamic viscosity of the emulsion with different contents of sunflower oil (Fig. 1) and the one of the protein base emulsifying capacity (Fig. 2) were conducted.

The studies of the temperature influence on the viscosity of the snack paste protein system with different contents of refined deodorized sunflower oil: $15 ; 20 ; 25 \%$ have established, that the dynamic viscosity in temperature diapason $90 \ldots 60{ }^{\circ} \mathrm{C}$ is practically equal and is near $\sim 0.5 \cdot 10^{3} \mathrm{~Pa} \cdot \mathrm{s}$.

The temperature decrease in diapason $50 \ldots 30{ }^{\circ} \mathrm{C}$ results in the viscosity growth within 1.0...4.0 $10^{3} \mathrm{~Pa} \cdot \mathrm{s}$. The increase of sunflower oil content in the milk base up to $30 \pm 2 \%$ results in the essential viscosity growth in temperature diapason $90 \ldots 60{ }^{\circ} \mathrm{C}$ within $0.75 \ldots 2.0 \cdot 10^{3} \mathrm{~Pa} \cdot \mathrm{s}$ and to the essential growth within $4.8 \ldots 13.5 \cdot 10^{3} \mathrm{~Pa} \cdot \mathrm{s}$ in temperature diapason $50 \ldots 30^{\circ} \mathrm{C}$ that may worsen emulsification conditions [13].

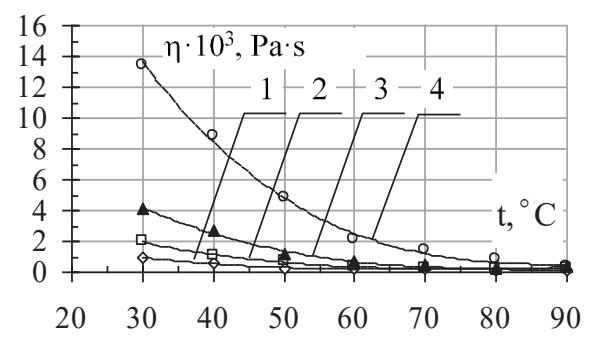

Fig. 1. Dependence of the viscosity of the snack paste protein base on temperature at sunflower oil content: $1-15 \%, 2-20 \%, 3-25 \%, 4-30 \%$

It is known, that emulsification is a process that takes place with essential energy consumption [5-8], so it is expedient to realize it in the zone with the low viscosity, that is why for emulsification we accept oil concentration $25 \pm 2 \%$, rational at temperature $30 \ldots 40{ }^{\circ} \mathrm{C}$, because it provides the lowest viscosity of the protein base at level $2.8 \ldots 4.0 \cdot 10^{3} \mathrm{~Pa} \cdot \mathrm{s}$.

It has been established (Fig. 2), that with the increase of sodium citrate concentration, the emulsifying capacity of the protein base E c grows and at concentration $2.0 \%$ reaches its maximal value -50 vol un of oil. At the further increase of sodium citrate concentration the emulsifying capacity decreases, probably as a result of $\mathrm{pH}$ growth (Fig. 2).

It has been proved (Fig. 2), that with the increase of fatless cottage cheese content from 30 to $40 \%$, the emulsifying capacity of the protein base intensively grows from 20 to $50 \mathrm{vol}$ un of oil. At the further increase of fatless cottage cheese content in the recipe, the emulsifying capacity doesn't grow, probably as a result of the essential viscosity increase.

The addition of dry skimmed milk in amount $4.0 \pm 0.5 \%$ as an additional emulsifier in the protein base at $40 \%$ of fatless cottage cheese favors an increase of its emulsifying capacity from 50 to 56 vol un of oil (Fig. 2), probably as a result of the growth of surface active substances [5, 7, 10, 14].

For products of the emulsion type with long storage terms, an important parameter is emulsion stability. It was determined by the content of non-destructed emulsion after twofold centrifuging with intermediate heating up to $90{ }^{\circ} \mathrm{C}$. 


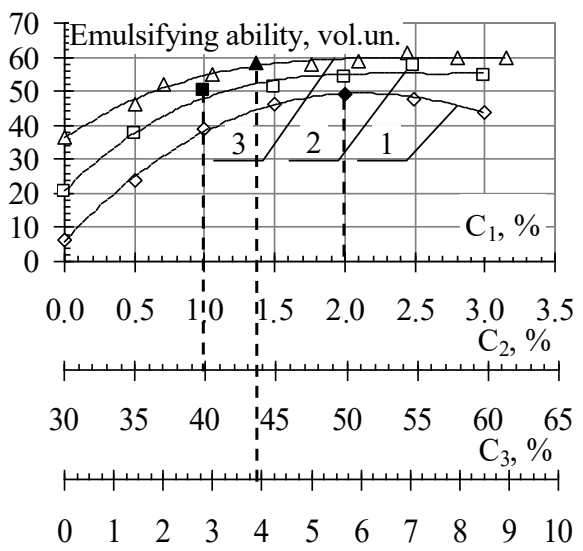

Fig. 2. Dependence of the emulsifying capacity of the snack paste protein base on concentration of main components: 1 - sodium citrate $(\mathrm{C} 1) ; 2$ - fatless cottage cheese $(\mathrm{C} 2)$;

$$
3 \text { - dry skimmed milk (C3) }
$$

It has been established, that the mass share of the non-destructed phase of the snack paste model emulsion before thermal processing (Table 2) depends on fat content, concentration of protein-containing components of the protein base and sodium citrate concentration $[15,16]$.

\section{Table 2}

The stability of the snack paste model emulsion before thermal processing

\begin{tabular}{|c|c|c|c|c|c|}
\hline \multirow[t]{2}{*}{ Component name } & \multirow{2}{*}{ Concentration, $\%$} & \multicolumn{4}{|c|}{$\begin{array}{l}\text { Mass share of non-destructed model emulsion, } \% \text { at fat content } \\
\text { (including vegetable oil), } \%\end{array}$} \\
\hline & & 20 & 40 & 60 & 80 \\
\hline \multirow{4}{*}{$\begin{array}{l}\text { Fatless cottage } \\
\text { cheese }\end{array}$} & 30 & 24 & 66 & 84 & 94 \\
\hline & 40 & 60 & 83 & 86 & 96 \\
\hline & 50 & 76 & 88 & 94 & 98 \\
\hline & 60 & 78 & 90 & 96 & 98 \\
\hline \multirow{4}{*}{ Dry skimmed milk } & 0 & 38 & 63 & 76 & 88 \\
\hline & 4 & 56 & 78 & 82 & 92 \\
\hline & 6 & 60 & 83 & 86 & 96 \\
\hline & 8 & 86 & 94 & 98 & 98 \\
\hline \multirow{4}{*}{ Sodium citrate } & 0 & 22 & 31 & 40 & 48 \\
\hline & 1 & 42 & 58 & 64 & 81 \\
\hline & 2 & 60 & 83 & 88 & 96 \\
\hline & 3 & 62 & 80 & 86 & 94 \\
\hline
\end{tabular}

The analysis of Table 2 testifies that the stability of the snack paste model emulsion at fat content $20 \ldots 80 \%$ is characterized by the mass share of the non-destructed structure correspondingly within $24 . .98 \%$, that depends on concentration of protein-containing components and also sunflower oil content in the recipe and active acidity of the protein base that also depends on sodium citrate concentration $[5,7,10]$.

The analysis of the right part of the diagram (Fig. 3) demonstrated that the stability of the model emulsion before thermal processing is high as $96 . .98 \%$ and almost doesn't depend on concentration of protein-containing components and sunflower oil within the studied concentrations. 


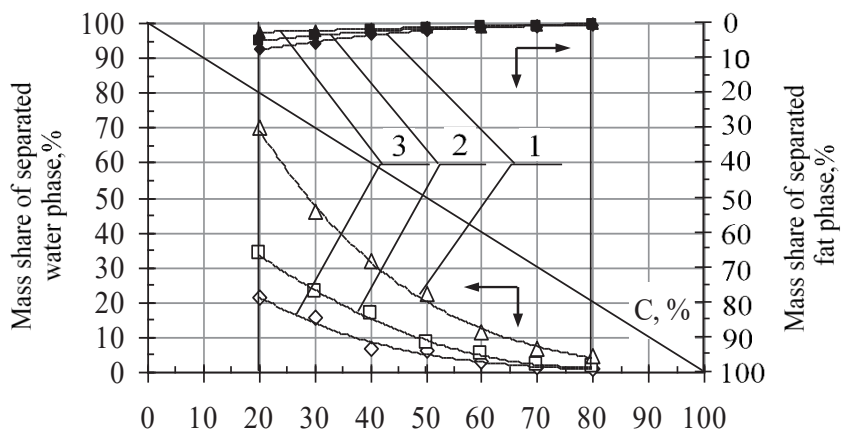

Fig. 3. Dependence of the stability of the model emulsion before thermal processing on sunflower oil concentration at fatless cottage cheese content, $\%: 1-30 ; 2-40 ; 3-50$

But the analysis of the left part of the diagram (Fig. 3) testifies that the kinetic stability is low and at sunflower oil content in the model emulsion $20 \pm 1 \%$, dry milk $4.0 \pm 0.5 \%$ and fatless cottage cheese in amount $30 \pm 2 \%, 40 \pm 2 \%, 50 \pm 3 \%$ is $30 \pm 2 \%, 65 \pm 2 \%, 78 \pm 2 \%$, respectively. The sunflower content increase from $20 . .80 \%$ at fatless cottage cheese concentration in the protein base $30 \%$ raises the emulsion stability by $70 \%$, at the further cottage cheese concentration increase up to $40 \%$ by $36 \%$, up to $50 \%$ by $22 \%$, and up to $60 \%$ by $20 \%$.

It has been established, that thermal processing at temperature $80 \pm 2{ }^{\circ} \mathrm{C}$ favors the stability increase of the snack paste model emulsion in almost 1.5 times (Fig. 4).

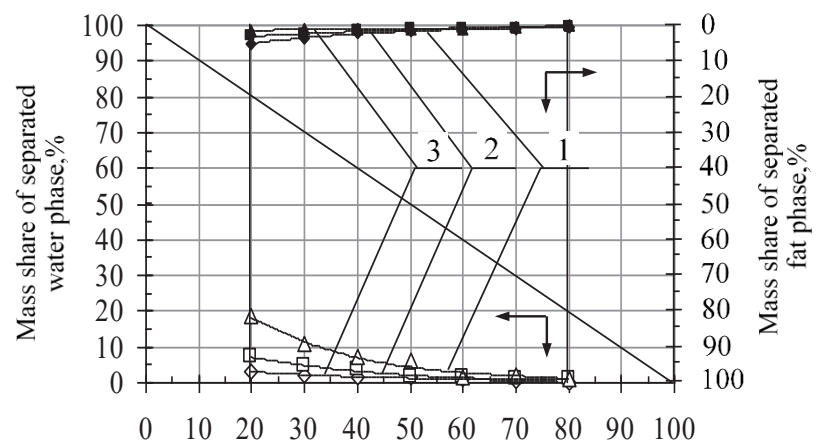

Fig. 4. Dependence of the stability of the model emulsion after

thermal processing on sunflower oil concentration at fatless cottage cheese content, $\%$ :

$$
1-30 ; 2-40 ; 3-50
$$

After thermal processing the stability of the emulsion, containing $20 \pm 1 \%$ of sunflower oil, grows at fatless cottage cheese content $30 \pm 2 \%$ up to $70 \%$, at $40 \pm 2 \%$ up to $84 \%$, at $50 \pm 2 \%$ up to $94 \%$ probably as a result of the increase of water binding by protein.

\section{Conclusions}

The studies have proved that the fat content of the snack paste model emulsion may have a wide diapason from 20 to $60 \%$ at keeping the aggregative stability.

It has been established, that the fatless cottage cheese content in amount $40 \pm 2 \%$ is a rational concentration in the snack paste model emulsion and provides necessary conditions for emulsification.

It is expedient to introduce dry skimmed milk in amount $4 \pm 1 \%$ in the recipe that raises the emulsifying capacity of the protein base by $28 \pm 2$ vol un of oil.

There has been proved the rational sodium citrate concentration in the protein base as $2 \pm 0.2 \%$, that provides the maximal emulsifying capacity as $50 \mathrm{vol}$ un of oil (Fig. 2).

It is also necessary to introduce in the recipe a structure former with a high water-binding capacity for providing the high kinetic stability of the snack paste model emulsion together with thermal processing. 
The conducted study allows to determine the rational concentrations of recipe components that may guarantee necessary rheological parameters of products of the emulsion type. It is planned to develop this study at elaborating technologies of fruit and dessert pastes, based on fatless cottage cheese. The obtained research results may be applied at producing melt cheeses, pastes, sauces, mayonnaises and other products of the emulsifying type, using milk-vegetable raw materials.

\section{References}

[1] Hurskyi, P. V., Pertsevyi, F. V., Hrynchenko, O. O., Savhira, Y. O., Polevych, V. V. (2003). Pat. No. 71798 UA. Method for production of a paste-like melted cheese of the emulsion type. No. 20031212544; declareted: 26.12.2003; published: 15.12.2004, Bul. No. 12.

[2] Bovkun, A. A. (2006). Syr'e dlya proizvodstva plavlenyh syrov. Molochnoe delo, 2, 46-47.

[3] Voliak, L. R., Galitska, A. S. (2019). Analysis of production of milk and milk products in Ukraine. Economy and Society, 19, 1393-1399. doi: https://doi.org/10.32782/2524-0072/2018-19-208

[4] Pertsevoy, F. V., Savgira, Yu. A., Kamsulina, N. V. et. al.; Pertsevoy, F. V. (Ed.) (2002). Tehnologiya polucheniya rastitel'nyh masel i pishchevyh produktov, obogashchennyh karotinoidami. Kharkiv: HGATOP, 229.

[5] Kolesnikova, M. B., Pertsevyi, M. F., Hurskyi, P. V. (2012). Doslidzhennia emulhuiuchoi zdatnosti bilkovo-zhyrovoi emulsiyi produktu strukturovanoho na osnovi syru kyslomolochnoho nezhyrnoho. Kharchova nauka i tekhnolohiya, 2, 95-97.

[6] Gurskiy, P. V., Biduk, D. O., Pertsevoy, F. V., Kolesnik, A. A. (2012). The research of structural and mechanical properties of emulsion on the basis of sunflower seed kernel. Eastern-European Journal of Enterprise Technologies, 1 (6 (55)), 7-10. Available at: http://journals.uran.ua/eejet/article/view/3389/3189

[7] Xu, W., Nikolov, A., Wasan, D. T. (2005). Shear-induced fat particle structure variation and the stability of food emulsions: II. Effects of surfactants, protein, and fat substitutes. Journal of Food Engineering, 66 (1), 107-116. doi: https:/doi.org/10.1016/ j.jfoodeng.2004.02.042

[8] Nykyforov, R., Gnitsevich, V. (2015). Rationale for the technology of emulsion sauces based on protein-carbohydrate semi-products. Eastern-European Journal of Enterprise Technologies, 3 (10 (75)), 15-19. doi: https://doi.org/10.15587/17294061.2015.43447

[9] Reo-viskometr po Geppleru. Sposob upotrebleniya (1987). VEB MLW Prufgerate-Werk Medingen, Sitz Freital, 18.

[10] Xu, X., Sun, Q., McClements, D. J. (2019). Enhancing the formation and stability of emulsions using mixed natural emulsifiers: Hydrolyzed rice glutelin and quillaja saponin. Food Hydrocolloids, 89, 396-405. doi: https://oi.org/10.1016/j.foodhyd. 2018.11.020

[11] Halukh, B., Paska, M., Drachuk, U. (2014). Emulsion stability of mayonnaise manufactured using dietary fiber. Naukovyi visnyk Lvivskoho natsionalnoho universytetu veterynarnoi medytsyny ta biotekhnolohiy im. Gzhytskoho, 16 (3 (4)), 21-30.

[12] Babenko, V. I., Bakhmach, V. O., Porosiuk, O. V. (2018). Determining the stability of mayonnaise emulsions based on liquid egg white. Vcheni zapysky TNU imeni V. I. Vernadskoho. Seriya: Tekhnichni nauky, 29 (1), 14-18.

[13] Yegya Raman, A. K., Aichele, C. P. (2019). Influence of non-ionic surfactant addition on the stability and rheology of particle-stabilized emulsions. Colloids and Surfaces A: Physicochemical and Engineering Aspects, 124084. doi: https://doi.org/ 10.1016/j.colsurfa.2019.124084

[14] Lei, J., Gao, Y., Ma, Y., Zhao, K., Du, F. (2019). Improving the emulsion stability by regulation of dilational rheology properties. Colloids and Surfaces A: Physicochemical and Engineering Aspects, 583, 123906. doi: https://doi.org/10.1016/j.colsurfa. 2019.123906

[15] Bortnowska, G., Balejko, J., Tokarczyk, G., Romanowska-Osuch, A., Krzemińska, N. (2014). Effects of pregelatinized waxy maize starch on the physicochemical properties and stability of model low-fat oil-in-water food emulsions. Food Hydrocolloids, 36, 229-237. doi: https://doi.org/10.1016/j.foodhyd.2013.09.012

[16] Pittia, P., Gambi, A., Lerici, C. R. (1997). Hygrometric measurements for the evaluation of the stability of model food emulsions. Food Research International, 30 (3-4), 177-184. doi: https://doi.org/10.1016/s0963-9969(97)00009-4 